\title{
SEROLOGICAL AND BIOLOGICAL DETECTION OF TOMATO MOSAIC VIRUS IN SOIL AND SEEDS OF TOMATO PLANTS IN DUHOK PROVINCE*
}

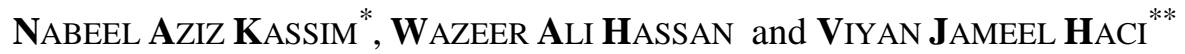 \\ *Dept. of plant protection, Faculty of Agriculture and Forestry, University of Mosul -Iraq \\ ** Dept. of plant protection, Collage of Agriculture Engineering Sciences, University of Duhok, \\ Kurdistan region-Iraq
}

(Received: March 6, 2019; Accepted for Publication: September 18, 2019)

\begin{abstract}
Tomato mosaic virus (ToMV) is one of the most important viruses on tomato; contaminated soil may be the main source and reservoir of transmission. Diseased plants were collected from Kamona and Xanike villages, Duhok province. DAS-ELISA technique its detection in the soil and contaminated seeds, and clarify the virus transmission from contaminated seeds to seedlings. Using indicator plants (Biological detection) was to identify virus from contaminated soil. The result showed that six samples out of 14 soil samples gave a positive reaction with $42.8 \%$ is transmission ratio from soil. Symptoms on indicator plants such as: mosaic, malformation, vein clearing on $C$. qinoa; the stunted plants with localized necrotic lesions and malformation on pepper plants. DASELISA from tomato seeds displayed in 11 samples out of 18 samples revealed strong reactions and seeds transmission proportion were $61 \%$. Seedlings were germinated from 60 infected tomato seeds under plastic house condition but only 4 transplants exhibited ToMV symptoms of mosaic, and the percentage of transmission was $7.8 \%$.
\end{abstract}

KEYWORDS: Tomato, Tomato mosaic virus, DAS-ELISA

https://doi.org/10.26682/ajuod.2019.22.2.1

\section{INTRODUCTION}

$\mathbf{T}$ omato (Solanum lycopersicum), Solanaceae. Is the most widely vegetable in the world, and the common components of the Mediterranean food, (Dorais et al., 2001; Chookhampaeng et al., 2008). It considered to be the second greatest important product after potato in the world, and an excellent source of healthy promoting agents due to contain of balanced mixture of vitamin $\mathrm{C}$ and $\mathrm{E}$, antioxidants, lycopene, lutein, B-carotene, flavonoids and minerals in its contents, (Dorais et al., 2008).

The viral diseases have been ranked as one of the important diseases of tomato, (Petrov, 2014). About 130 viruses are known to infect tomato worldwide, (Hanssen et al., 2010) and cause between 20-90\% losses in production, (Hameed, 1995).Tomato mosaic virus (ToMV) is the most important Tobamoviruses infecting tomato (Hanssen, et al., 2010; Li, et al., 2013). ToMV belongs to Tobamovirus genus (Francki et al., 1985) and belong to the family Virgaviridae (King,
2011). It is stable RNA virus wide-spread in distribution and infects many plant species (Hollings and Huttinga, 1976). Four strains of ToMV were recognized on tomato (Tm- 0 , $\mathrm{Tm}-1, \mathrm{Tm}-2, \mathrm{Tm}-2^{2}$ ) based on resistance (R) genes (Pelham, 1966; Hall, 1980).

Symptoms of infected tomato crop including appearance of curling, mosaic, leaf distortion, uneven ripening and internal browning of fruit. In susceptible cultivar ToMV provokes serious disease in tomato plant drastically reducing yield (Najeeb Ullah, et al., 2017). Average incidence of disease caused by this virus ranged between 25.49- $29.79 \%$ in tomato seeds and leaves (Khan, 1997). While Arinaitwe (2013) found that the incidences of ToMV were more than $60 \%$ in field samples with high level of mixed virus infection.

Under adverse environmental condition ToMV is quite stable and can persist in moist soil for a month or in dry soil for two years or in fallow soil at $120 \mathrm{~cm}$ in root debris for 22 months, (Yadav and Yadav, 2017). 
Contaminated soils play roles as reservoirs and source of ToMV transmission (Yang et al., (2012). Tobamoviruses stay in soil with plant debris. Therefore, the soil serves a primary source of inoculum of later crops (Broadbent, 1965; Nagai, 1981; Lanter et al., 1983; Pares and Gunn, 1989). The viral particles are identified to be absorbed to organic plant debris and clay particles, (Kegler et al., 1995). ToMV can be transport through soil and water from diseased to healthy plant; then can enter the plant via roots and cause infection, (Schwarz et al., 2010).

ToMV is seed-borne and seed transmission (Broadbent, 1976; Gooding and Suggs, 1976; Chitra et al., 1999).Virus contamination the seed coat of tomato and usually transfer externally (Pradhanang, 2005). The virus is present in external and sometimes endosperm of tomato seed, but was not showed within embryo (Broadbent, 1976).

ToMV transmission by tomato seed has been study widely (de Assis Filho and Sherwood, 2000), the rate of seed transmission of ToMV reach up to $94 \%$ while less than $1 \%$ seed transmission rate is enough to serve as inoculum for epidemic due to mechanical transmission (Broadbent L.1965; Brunt, et al., 1997).

The current work aimed to identify ToMV on symptomatic tomato plants using DASELISA (double antibody sandwich-enzyme linked immunosorbent assay) and determine its transmission by soil and tomato seeds at first time in Duhok province.

\section{MATERIALS AND METHODS Field survey to detect ToMV from soil sample and tomato fruit}

Soil samples were collected in October 2018 from the selected tomato fields surveying place in Semel, Duhok Province in the area of Khanke and Kamona villages. Each sample weighed 2-3 kg, was taken from the rhizosphere of infected tomato plants at 5$30 \mathrm{~cm}$ soil depth. Samples were bagged, labeled properly and transferred to the laboratory of Plant Pathology, collage of Agriculture Engineering Sciences, University of Duhok.
During the field visits, 18 symptomatic tomato plants were selected, after confirming that the virus has detected by DAS-ELISA test, each plant were labeled until harvesting. The fruits were also collected at full ripening. Soil samples, tomato plants and fruits were used for detection ToMV using DAS-ELISA. Examining the presence of the ToMV in soil samples

DAS-ELISA method was used to detect ToMV in soil samples, according to Clark and Adams (1977) and instructions of antiserum manufacture ("Agdia", France)

Capture antibody (IgG) solution was prepared and diluted with $10 \mathrm{ml}$ carbonate coating buffer, mixed with $50 \mu \mathrm{l}$ of capture antibody, and pipette $100 \mu \mathrm{l}$ into each well. The plate incubates for $4 \mathrm{hrs}$. at room temperature before washing by PBS-Tween two times. Mixed soil sub-sample 50gm was taken and washed with $100 \mathrm{ml}$ of phosphate buffer plus drops of Tween. The samples are shaken on the rotary shaker (200 rpm) for 45min; the soil extract was filtered with a double layered of muslin cloth in a clean beaker and $5 \mathrm{ml}$ of soil extraction was mixed with $1 \mathrm{ml}$ of general extract buffer (GEB). Plate incubates for 2 hour at room temperature, then washed 7 times as mentioned previously. Prepare enzyme conjugate 10 minutes before use: you should be added $10 \mathrm{ml}$ ECI (enzyme conjugate) buffer with $50 \mu \mathrm{l}$ of enzyme conjugate. Incubate plate for 2 hour at room temperature. Plate washed 8 times with PBST. Prepared PNP solution: each PNP tablet made $5 \mathrm{ml}$ of PNP solution, and dispensed $100 \mu \mathrm{l}$ of PNP substrate into each wells. Incubated the plate for 60 minutes.

Examining the presence of the virus in soil samples biologically using bait plants

The ToMV infested soil samples were transported into pots $13 \mathrm{~cm}$ in diameter. Healthy seeds of each pepper (Capsicum annum) and goosefoots plants (Chenopodium quinoa) were planted at a rate of 5seeds/pot (Buttner and Nienhuase, 1980), to determine whether the with virus presence. The experiment was conducted under plastic house in collage of Agriculture during 2018. Plants were observed visually for checking the appearance of viral symptoms. 
Examining the presence of the virus in tomato GC cultivar seeds by DAS-ELISA

ELISA was reliable technique and very sensitive for detection of virus, nowadays suitable for testing seeds (Morrison, 1999). DAS-ELISA method was used to detect ToMV in tomato seed, according to Clark and Adams (1977) and instructions of antiserum manufacture ("Agdia", France).

Full ripening tomato fruit were crushed to obtain seeds. Five infected tomato seeds from each sample were grounded by pestle and mortar blinded with General Extract Buffer (GEB) at $\mathrm{pH} 7.4$, at ratio of 5:10 (W/V) then passed through double layered muslin cloth to remove the seed derbies and then diagnosed by DAS-ELISA.

Examining the percentage of natural transmission of the virus by seeds

Fully ripped tomato fruits (GC hybrid) were crushed to obtain seeds, 60 seeds of infected tomato were planted in sterilized container wooden box $(50 \times 20 \mathrm{~cm})$ containing of autoclaved soil and peatmoss $(3: 1, w / w)$ in lines $10 \mathrm{~cm}$ interval with $5 \mathrm{~cm}$ between seeds .This experiment was conducted in the green house at Collage of Agriculture Engineering Sciences, University of Duhok. The plants were maintained for up 2 months to observe the appearance of systematic symptoms (Sevik, and Tohumcu, 2011).

\section{RESULTS AND DISCUSSIONS Detection of virus in soil samples by DAS- ELISA:}

The results showed that six samples out of 14 soil samples gave a positive reactions with $42.8 \%$ soil transmission rate. Due to reasons for example soil infestation in previous season was more so soil infestation with virus will be more.

The positive DAS-ELISA characterized by the yellow color of substrate solution as shown in (Fig. 1). In this aspect Yang et al., (2012) and Fillhart, et al., (1998) were applied DAS-ELISA for detection ToMV in the soil with distinct rate of $5 \%$.

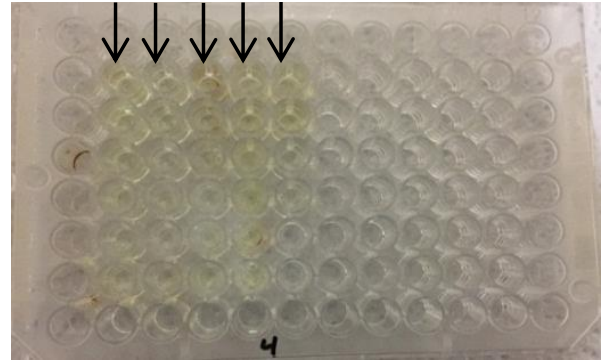

Fig. (1): DAS-ELISA test, Appearance of yellow color in the $2^{\text {nd }}$ to $4^{\text {th }}$ columns which indicates the presences of ToMV in soil samples.

\section{Biological detection of ToMV using indicator plants}

The virulent ToMV particles in tested soils resulted in varied symptomatic plants of Chenopodium quinoa and pepper (Capsicum annum) after four weeks of inoculation (Fig.2).

Symptoms included mosaic, malformation, vein clearing on pepper plants; the stunted plants with necrotic lesions were most common. These symptoms were also described by Madhusdhhan et al., (2005). Kumar et al., (2011) observed symptoms of leaf curling, mosaic and stunted growth on pepper. In contrast the necrotic lesions were developed on C. qinoa (Fillhart et al., (1998).

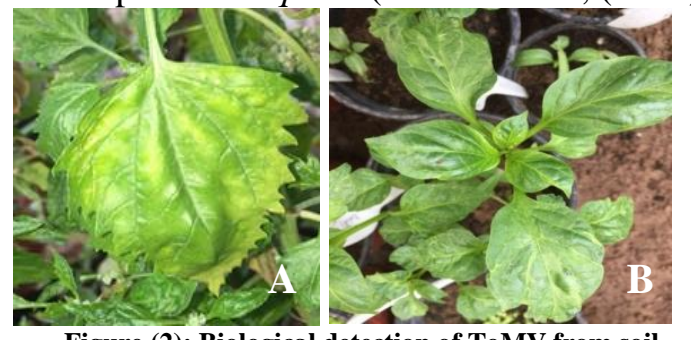

Figure (2): Biological detection of ToMV from soil, appearance the symptoms of ToMV on Chenopodium quinoa (A) and pepper plant (B).

\section{Detection of ToMV in tomato seeds by DAS-ELISA}

The ToMV survived in seeds identified by using DAS-ELISA. Eleven samples out of 18 samples revealed strong reactions (Fig.3). The percentage of the literatures demonstrated the highest occurrence ToMV of infected tomato seeds reached $61 \%$. Almeida et al., (2018) and Van Winckle and Gcypens (1965) were reviewed the frequency of viral transmission by tomato seeds reached to $98 \%$ and $94 \%$ respectively, Hadas et al., (2004) reported that ToMV contaminated $78.8 \%$ tomato seeds. Reasons may be the 
differences in infection percentages is attributed to the different cultivars of tomato studied.

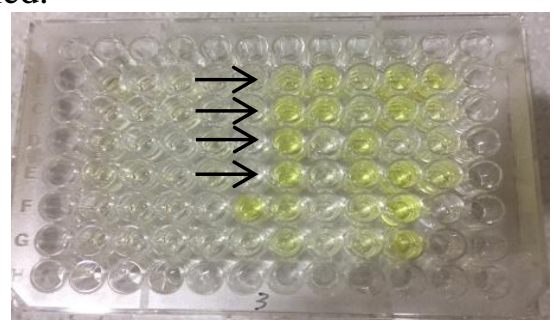

Fig (3): DAS-ELISA test. Appearance of yellow color in the $7^{\text {th }}$ to $11^{\text {en }}$ columns, indicated the presences of ToMV in mature tomato seeds.

\section{Estimation of natural transmission percentage of the virus by seeds}

Seedlings were germinated from 60 infected tomato seeds under plastic house conditions but only 4 exhibited ToMV symptoms of them (mosaic) as shown in (Fig.4), the virus succeeded to pass from seed coat to penetrate seedlings tissues causing systemic infection and the percentage of transmission was $7.8 \%$. The similar results were found by (Sevİk, and Kose-tohumcu, (2011) with the rate transmission of $23.5 \%$.

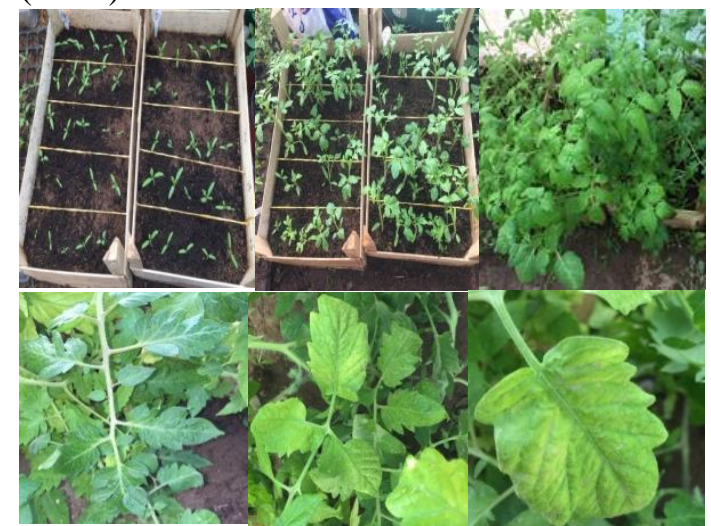

Fig. (4): Transmission of ToMV from seeds to seedling test, as shown by symptoms of ToMV .

\section{CONCLUSION}

We concluded that the ELISA test showed high efficiency in detection Tomato mosaic virus (ToMV) in soil samples, and also in tomato seeds obtained from infected fruits, the percentage of its presence in soil samples were $42.8 \%$, and in seeds $61 \%$.

The indicator plants of pepper ( Capsicum annuиm) and goosefoots (Chenopodium quinoa) were successfully used for the purpose of catching of ToMV from infested soil , because they infected systemically when planted in such soil, The biological test had been validated in the detection of ToMV in soil. The results of presence ToMV in the contaminated tomato seeds revealed the restricted ability of a pathogen to pass from seed coat to tomato seedlings and not exceed than $7.8 \%$ when planted contaminated seeds in sterile soil. Thus, the high rate of infested seeds with ToMV.

\section{REFERENCE}

Agdia-EMEA (2018). Easy-to-use test kits, reagents and laboratory testing services for agricultural diagnostics. www.agdiaemea.com.

Arinaitwe, W. (2013). Incidence, symptom severity and distribution of tomato viral diseases in Uganda. M.Sc. Thesis, Makerere University. Kampala, Uganda.70pp.

Almeida J. E.M., Figureira A. D.R., Duarte P.S.G., Lucas M.A. and Alencar N.E. (2018). Procedure for detecting Tobamovirus in tomato and pepper seeds decreases the cost analysis. Bragantia, vol.77, No. 4, p. 590-598.

Broadbent, L. (1965). The epidemiology of tomato mosaic XI. Seed transmission of TMV. Ann. Appl. Biol. 56:177-205.

Broadbent, L., 1976. Epidemiology and control of Tomato mosaic virus. Annual Reviews of Phytopathology, 14:76-96.

Broadbent, L., W. H. Read, and F. T. Last. 1965. The epidemiology of tomato mosaic. X. Persistence of TMV-infected debris in soil, and the effects of soil partial sterilization. Ann. Appl. Biol. 55:471-483.

Brunt, A.A., Crabtree, K., Dallwitz, M.J., Gibbs, A.J., Watson, L. \& Zurcher, E.J. (eds.). (1997). `Plant Viruses Online: Descriptions and Lists from the VIDE Database.http://sdb.im.ac.cn/vide/descr832 .htm.

Buttner, C. and Nienhaus, F. (1989). Virus contamination of soils in forest ecosystems of the Federal Republic of Germany. - Eur. J. Forest Pathol. 19: 47-53. 
Chitra T.R., Prakash H.S., Albrechtsen S.E., Shetty H.S., Mathur S.B., 1998. Seed transmission of ToMV in tomato and TMV in bell pepper. Tropical Science (in press).

Chitra, T.R., H.S. Prakash, S.E. Albrechtsen, H.S. Shetty, and S.B. Mathur. 1999. Infection of tomato and bell pepper by ToMV and TMV at different growth stages and establishment of virus in seeds. J. Plant Pathol. 81:123-126.

Chookhampaeng, S., Pattanagul W. and Theerakulpisut, P., 2008. Effects of Salinity on Growth, Activity of Antioxidant Enzymes and Sucrose Content in Tomato (Lycopersicon esculentum Mill.) at the Reproductive Stage. Science Asia 34: 069-075.

Clark, M. F. and A. N. Adams (1977) Characterization of the microplate method of the enzyme-linked immunosorbent assay for the detection of plant virus. J. Gen. Virol., 34:475-483.

de Assis Filho, F.M. and Sherwood, J.L. 2000. Evaluation of seed transmission of turnip yellow mosaic virus and tobacco mosaic virus in Arabidopsis thaliana. Phytopatho. 90:1233-1238.

Dorais M, Papadopoulos AP, Gosselin A, 2001. Influence of electric conductivity management in greenhouse tomato yield and fruit quality. Agronomie 21:367-383.

Dorais, M., Ehret, D.L., Papadopoulos, A.P. (2008): Tomato (Solanum lycopersicum) health components: from the seed to the consumer. - Phytochem Rev. 7: 231-250.

Fillhart R.C., Bachand G.D. and Castello J.D., (1998). Detection of Infectious Tobamoviruses in Forest Soils. Applied and environmental microbiology, vol.64, No.4, p. 1430-1435.

Francki, R.I.B., R.G. Milne and T. Hatta. 1985. Atlas of Plant Virus. Vo. II, CRC Press, Florida, 284-285.

Gooding Jr, G.V. and E.G. Suggs. 1976. Seedborne tobacco mosaic virus in commercial sources of tomato seed. Plant Dis. Rept. 60:441-442.

Hadas, R., Pearlsman, M., Gefen, T., Lachman, O., Hadar, E. and Sharabany, G., (2004). Note: Indexing system for Tomato Mosaic Virus (ToMV) in commercial tomato seed lots. Phytoparasitica, vol. 32, No.4, p.421424.

Hall, T.J. 1980. Resistance at Tm-2 locus in tomato to Tomato mosaic virus. Euphytica 29:189-197.

Hameed, S. 1995. Leaf curl virus resistance in tomato and chilies. Final Report, South Asian Vegetable Research Network. Virology Section (CDRI), NARC, Islamabad.

Hanssen IM, Lapidot M, Thomma BPHJ (2010) Emerging viral diseases of tomato crops. Mol Plant Microbe Interact 23:539-548.

Hoggan, I. A.. 1. Johnson (1936): Behaviour of the ordinary Tobacco mosaic virus in the soil. J. Agric. Res. 52, 271294.

Hollings, M., and H. Huttinga. 1976. Tomato mosaic virus. Descriptions of plant viruses, no. 156. Commonwealth Mycological Institute/Association for Applied Biology, Kew, England.

Kegler, H., Fuchs, E., Spaar, D. and Kegler, J. (1995) Viren in Boden und Grundwasser (Viruses in soil and groundwater). Archives of Phytopathology and Plant Protection 29, 349-371.

Khan, I.A. 1997. Occurrence, distribution, host range, symptomoly and purification of ToMV on tomato. Pak. J. Zool. 29(4): 385389.

King, A.M., M.J., Adams, E.J. Lefkowitz and E.B. Carstens. 2011. Virus taxonomy: IXth report of the International Committee on Taxonomy of Viruses.

Kumar, S., Udaya Shankar, A. C., Nayaka, S. C., Lund, O. S. and Prakash, H. S. (2011). Detection of Tobacco mosaic virus and Tomato mosaic virus in pepper and tomato by multiplex RT-PCR. Letters in Applied Microbiology. Vol.53, No.3, p. 359-363. 
Lanter, J. M., J. M. McGuire, and M. J. Goode. 1983. Persistence of Tomato mosaic virus in tomato debris and soil under field conditions. Plant Dis. 66:552-555.

Li R, Gao S, Fei Z, Ling KS (2013). Complete genome sequence of a new tobamovirus naturally infecting tomatoes in Mexico. Genome Announc 1(5). doi:10.1128/genomeA.00794-13.

Madhusudhan K.N., Nalini M.S., Prakash H.S. and Shetty H.S. (2005). Effect of Inducer against Tobamovirus Infection in Tomato and Bell Pepper. International Journal of botany $1(1)$, p. 59-61.

Morrison R.H. 1999. Sampling in seed health testing // phytopathology., vol.89, p. 10841087.

Nagai Y., (1981). Control of mosaic disease of tomato and sweet pepper caused by tobacco mosaic virus. Spec.Bull. Chiba Agric. Exp. Stn. 9: 1-109 (in Japanese with: English summary).

Pares, R.D. and Gunn, L.V. (1989). The role of non-vectored soil transmission as a primary source of infection by pepper mild mottle and cucumber mosaic viruses in greenhouse-grown capsicum in Australia. J. Phytopathol. 126: 353-360.

Pelham, J. 1966. Resistance in tomato to tobacco mosaic virus. Euphytica 15:258-267.

Petrov N. (2014). Damaging effects of tomato mosaic virus and potato virus $Y$ on tomato plant. Science \& Technologies.Vol. IV, No. 6.
Pradhanang P. M. , Greonwegen K. and Ozminkowski et al., 2005. Tobacco mosaic virus: does it really transmit through tomato seed? (Abstract): 5th ISTA-SCH seed health symposium.- Angers, France.

Sevİk, M. A and Kose-tohumcu, E. (2011). The ELISA analysis results in tomato (Lycopersicon esculentum Mill) seed health testing for Tobacco mosaic virus. Zemdirbyste Agriculture. vol. 98, No. 3, p. 301-306.

Sutic, D.D., R.E. Ford and M.T. Tosic. 1999. Handbook of Plant Virus Diseases. CRC Press.

Najeeb Ullah, N., Ali, A., Ahmad, M., Fahim, M., Dini,N. and Ahmad, F. (2017). Evaluation of tomato genotypes against tomato mosaic virus (ToMV) and its effects on yield contributing parameters. Pak. J. Bot., 49(4): 1585-1592.

Van Winckel, A. and Gcypens, M. (1965). Inactivering van Tabakmosaiekvirus in de grond. Parasitica, 11, 124-137.

Yadav K. And Yadav P., (2017). The effect of different mechanism of transmission on transavaibility of Tomato Mosaic Virus. Journal of Pharmacognosy and Phytochemistry,Vol. 6,No. 6, p. 448-450.

Yang, J.G, Wang, F.L., Chen D.X., Shen, L.L., Qian Y.M., Liang Z.Y., Zhou W.C. and Yan T.H. (2012). Development of a onestep immunocapture real-time RT-PCR assay for detection of Tobacco mosaic virus in soil. Sensors (Switzerland), vol. 12, No.12, p. 16685-16694. 


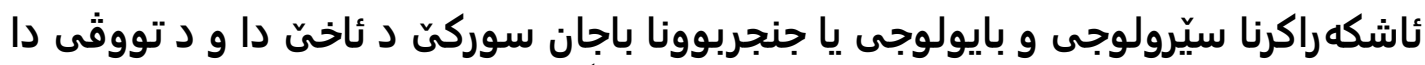

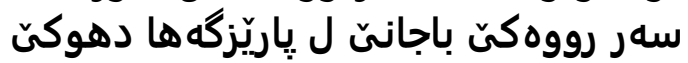

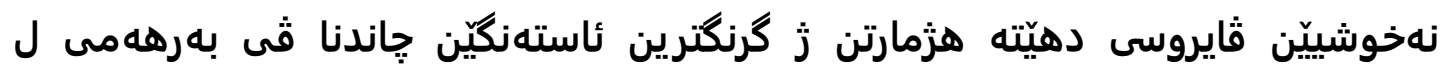

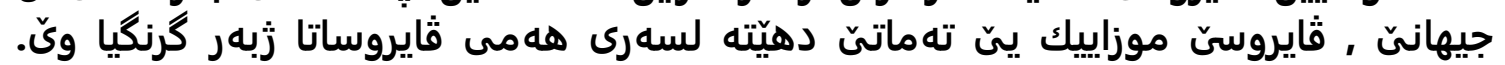

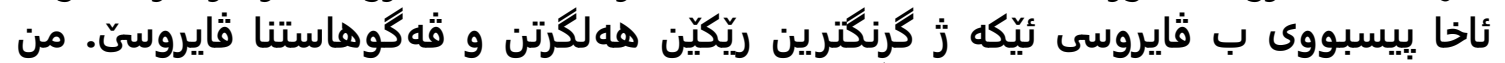

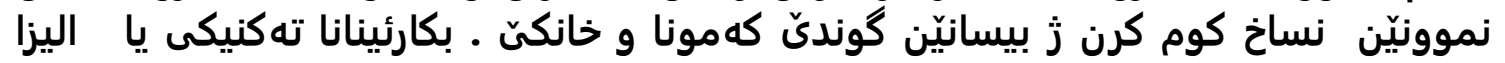

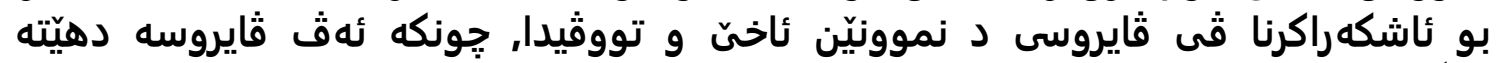

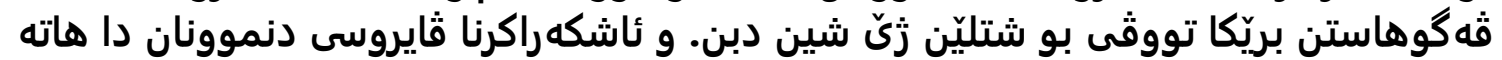

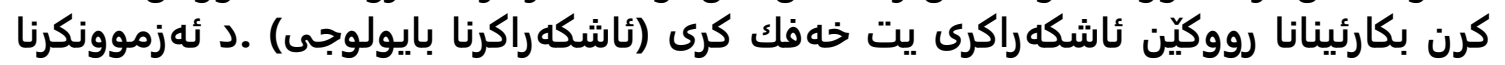

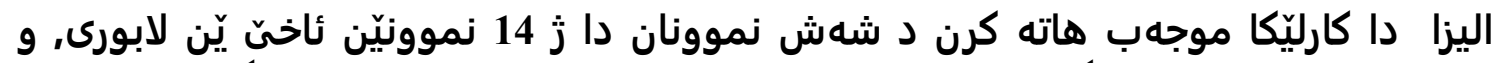

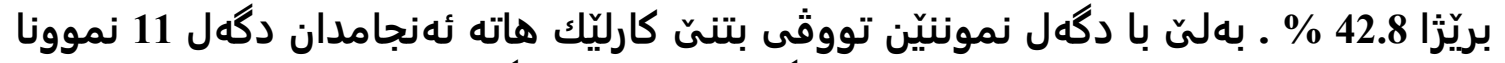

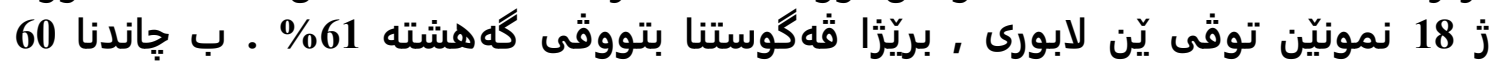

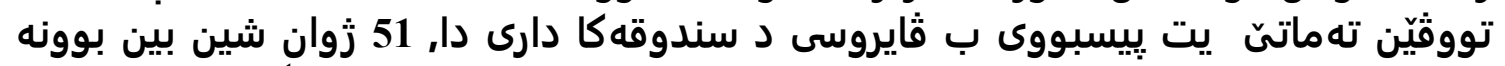

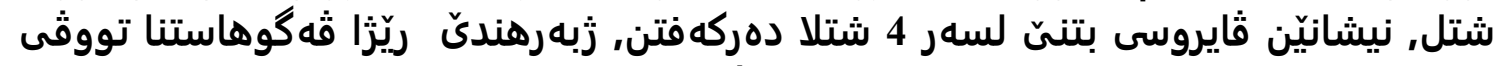

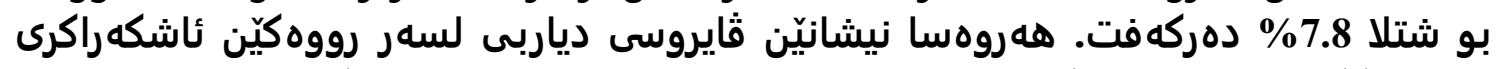

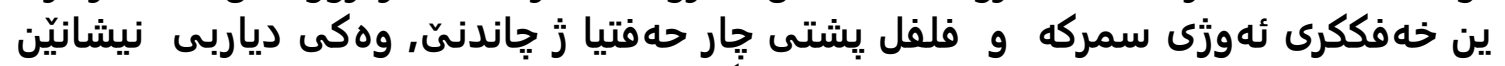

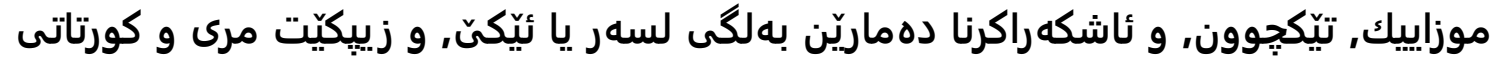
دهركهت لسهر يا دوونيك.

الكشف الحيوي والمصلي عن فايروس موزائيك الطماطة Tomato mosaic virus في التربة والبذور في محافظة دهورك الئيك

الخلاصة

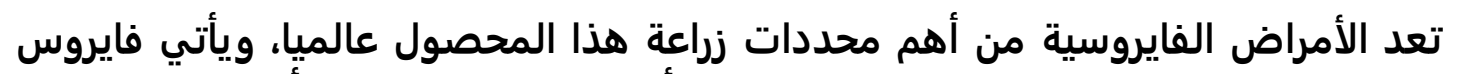

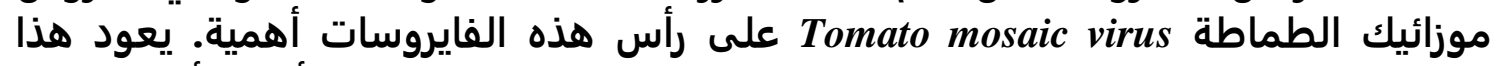
الفايروس الى الجنس Tobamovirus، وقد تكون التربة الملوثة به هي هي أحدائ أحدى أهم أهمية وسائل الاحتفاظ به ونشره. جمعت العينات المصابة من حقول قريتي "كمونة" و و ل Xanike .

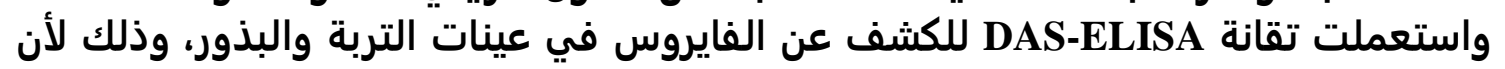

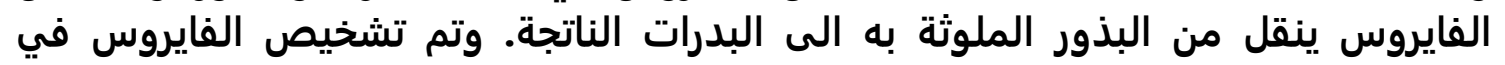




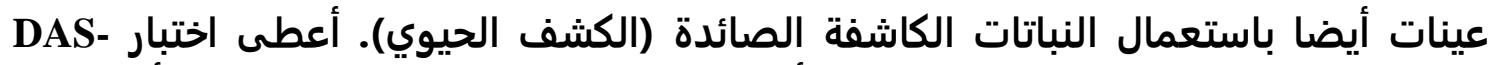
ELISA

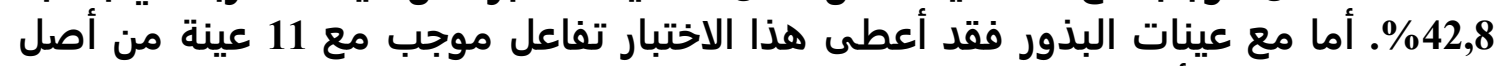

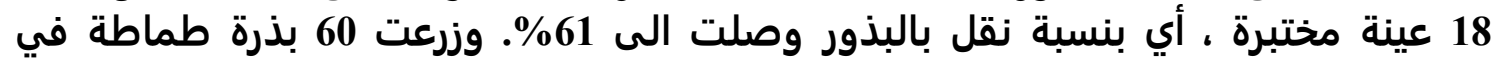

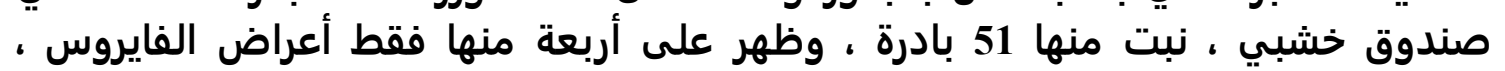

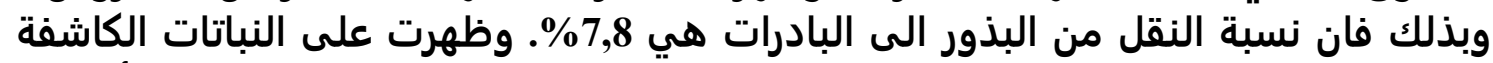

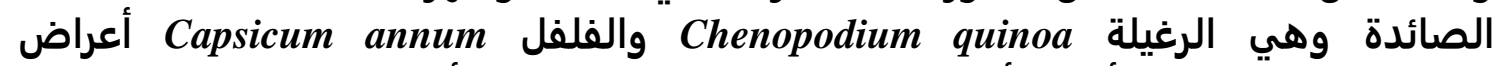

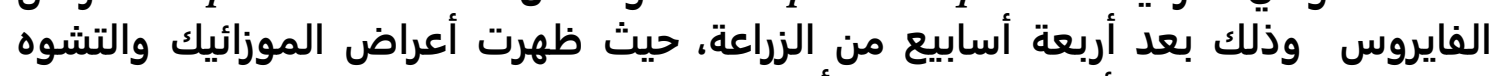
ووضوح العروق على الأول، فيما ظهرت أسبع أعراض البراعة حيثع الميتة والتقزم على الثاني. 